\title{
DEVELOPMENT OF INFORMATION CULTURE OF A TEACHER IN THE CONDITIONS OF DISTANCE LEARNING
}

\author{
Bohdan Ivashchenko ${ }^{1}$, Olena Habelko ${ }^{2}$, Yaroslav Haleta ${ }^{3}$ \\ ${ }^{1}$ Postgraduate student, Volodymyr Vynnychenko Central Ukrainian State Pedagogical University, \\ Kropyvnytskyi, Ukraine, e-mail: ivashchenkobi@gmail.com, ORCID: https://orcid.org/0000-0003-4363- \\ 0726 \\ ${ }^{2}$ Ph.D. (Pedagogy), Candidate of Pedagogical Sciences, Associate Professor, Volodymyr Vynnychenko \\ Central Ukrainian State Pedagogical University, Kropyvnytskyi, Ukraine, e-mail: lena_gabelko@i.ua, \\ ORCID: https://orcid.org/0000-0003-3769-3616 \\ ${ }^{3}$ Doctor of Sciences (Pedagogy), Professor, Volodymyr Vynnychenko Central Ukrainian State Pedagogical \\ University, Kropyvnytskyi, Ukraine, e-mail: yaroslavhaleta@ukr.net, ORCID: https://orcid.org/0000-0003- \\ 0484-529X
}

Abstract. The article deals with the peculiarities of distance learning. The factors, which influence the information environment, have been given. The newest technologies and methods used in distance learning are considered. The main components of information culture, which develop in the conditions of distance learning, have been listed. After the scientific sources analysis, generalization of native and foreign experience of the organization of distance education in higher educational establishments, the theoretical basis of organization of the remote education for the are stated. Pedagogical conditions of the organization of the distance education for the students of the pedagogical university are determined and checked in practice. Addressing them is relevant and important psycho-ducational problems, the solution is able to improve the efficiency of the educational process. The features of the impact of distance education on the individual as a member of academic cooperation. It was concluded that distance education is the most promising direction of development of education in general, especially the modernization of educational technology contents and professional education is a huge psychological - pedagogical potential.

Keywords: professional education, augmented reality, gamification, technological culture, semiotic culture, communicative culture.

JEL Classification: A22, I23

Formulas: 0; fig.: 0; tabl.: 0; bibl.: 10.

Introduction. The pandemic affected all aspects of life, especially the educational process. Distance education was used mainly for the organization of higher education, but recently the percentage of this education has increased several times. Though, as it turned out, many were unprepared, both teachers and students.

The development of modern models of education based on distance learning is becoming a priority in the modernization of higher education in Ukraine and abroad. The increase in distance education programs in the structure of university education for master's and graduate students reflects current trends in the integration of innovative research centers and university science, as well as the globalization of the information educational environment.

The expansion of distance educational technologies has strengths and weaknesses. On the one hand, these technologies meet the modern demands of individualization of education: the possibility of combining work, education and selfeducation; raising the level of education of masters and graduate students, provided they participate in research projects. On the other hand, the uneven development of the information educational environment in Ukrainian universities, as well as different levels of mastery of information and media culture hinders the 
implementation of equal opportunities in choosing forms of educational programs by representatives of the university community in Ukraine and foreign universities.

Literature review. Scientists V. Yu. Bykov and M. P. Shishkin paid attention to the use of cloud-oriented networking tools to inform the content of the open educational environment of higher education institutions. Researcher O. M. Samoilenko considered audiovisual means of the web-resource in the context of mastering physical and mathematical disciplines, namely the training of a mathematics teacher. Scientists P. P. Nechipurenko, S. O. Semerikov, T. V. Selivanov, T. O. Shenaev considered the problem of forming research competencies in chemistry teaching using information and communication training tools. In his research, researcher O. I. Bashkir paid attention to interactive teaching methods. In the research of G. D. Pospelova examines the use of audiovisual training tools in the preparation of future agronomists, and focuses on the use of video materials.

Despite the significant amount of research, the problem of information education in distance learning does not have a definite solution, and in the future, there will be new factors that will affect the quality of distance learning.

Aims. Highlight the features of the use of distance learning to form the information culture of the future teacher.

Methods. The authors used methods of logical comparison, systematization and generalization, which allowed to achieve the aims of the study and draw conclusions.

Results. First, let us look at what we mean by information culture. Information culture in the modern information society should be considered not only as a measure of human formation for an organic entry into the information society, the cultural space of this society, but also as the achieved level of organization of information processes; the degree of satisfaction of people in information communication; the level of efficiency of creation, collection, storage, processing, transmission, presentation and use of information, which provides a holistic view of the world, anticipation of the consequences of decisions. As a product of the development of the information society, information culture is a broader concept than man-made culture and includes all its basic characteristics that do not contradict the development of civilization. At the same time, new components appear that act as patterns of information culture, which are characteristic only of the information society that has formed as a whole and its information and communication technologies (communication and interpersonal communication, information security, information services, etc.).

Mastering information culture is a way to universalize human qualities, which contributes to a person's real understanding of himself, his place in life. An important role in the formation of information culture is played by education, which should prepare a specialist for the information community, developing his skills and abilities: differentiation of information; selection of significant information; establishing criteria for evaluating information; creation of information and its use [2].

In the process of forming the information culture of the university student, along with the study of theoretical disciplines of the information field, a lot of time should 
be devoted to computer information technology, which is a basic component of the future field of activity. In addition, the quality of training should be determined by the degree of established sustainable skills in the field of basic information technology in solving typical professional tasks.

The practical side concerns the actual application of all these innovations in the learning process, for which this law provides for two stages of implementation of these innovations:

- the first is the introduction of digital (technological) literacy lessons into the curriculum, that is, the teaching of students to use them in the learning process;

- the second is the practice of improving educational processes by technology, or the possibility of "digital education" (such a term is specified in the law, meaning it is a full-fledged training practice provided with technological means) [8].

Distance learning, which we consider as one of the conditions for the formation of information culture must meet the following pedagogical provisions:

1. The central place in the learning process is occupied by independent cognitive activity of the student. Only by realizing in the learning process the need for independent acquisition and application of knowledge, as well as the formation of the necessary competencies, the student will be able to fully realize their educational potential.

2. The most important, as a result of learning, is mastering the amount of knowledge, and the ability to search independently, acquire knowledge and experience with information. It is necessary that as a result of training the graduate possesses ways of continuous cognitive activity which he could apply in the further life.

3. Independent activity of students should be organized with the use of the newest pedagogical technologies promoting formation of social qualities of the person (ability to carry out various social roles, work in collective for performance of difficult educational tasks).

4. Distance learning should not exclude the possibility of communication between student and teacher, students with each other, but on the contrary, should facilitate such communication to solve problems of socialization of students.

5. Control and feedback systems should be not only systematic but also operational and carried out at all levels of development of the educational program in the discipline.

Distance learning allows you to combine the student's independent cognitive activity with a variety of sources of information, teaching materials provided by the teacher, various feedback and control mechanisms, communication within the course with the teacher, consultants and other students, group, project and research work. This comprehensive approach to the organization of the learning process allows not only to master the educational material effectively, but also to form the personal qualities of the student, in particular, information culture.

By placing the student in a programmed information environment, we create conditions not only for the acquisition of new knowledge, but also create conditions for the conscious need to acquire knowledge, work with information to achieve the 
objectives. When implementing e-learning, the educational institution develops methodological support, prepares a software environment for the functioning of the distance learning system, trains teachers the skills of distance learning, but often overlooks the important principle of starting knowledge [1].

The factors that determine the level of development of the information educational environment include:

- the level of autonomy of universities (financial, economic, scientific, technical, cultural);

- the level of funding of universities by public authorities and private firms;

- legal, financial and economic forms of state support aimed at improving information culture;

- availability of developed educational standards to increase information and media literacy;

- developed network of electronic libraries [4].

Another important factor for the formation of information culture of the future teacher in the conditions of distance learning is the presence of a teacher-tutor.

The development of the educational system, even in the digital Internet space, is impossible without human participation. Thus, a new profession, a tutor, enters the "stage" of teaching. In English "Tutor" means "home teacher, mentor, guardian". Today, the tutor is a central figure, officially recognized as part of the English university system. Obviously, a tutor is not just a teacher. In the system of distance learning it has new functions, new roles that were absent in the traditional system [11].

In the modern educational process, the tutor is simultaneously:

- teacher (serves as a source of knowledge, skills, abilities and professional experience);

- consultant (answers questions from students on the course, gives recommendations for tasks, helps students to develop information resources on the Internet, etc.);

- organizer of the learning process (organizes joint activities of students, manages the interaction of students during training, solves organizational and administrative issues);

- facilitator (creates favorable conditions for learning);

- inspirer (stimulates creative activity of students, encourages them and inspires them to independently search for knowledge);

- designer (designs the forms of organization of the educational process and activities most relevant to the goals and content of the course being studied) [5].

In addition to all the above factors influencing the formation of information culture, it is important to use new methods and technologies of distance education.

One of them gamification (or gamization) is the use of game approaches for non-game processes in order to increase the involvement of participants in solving applied problems.

Gamification usually aims to engage the student in learning just as a computer game involves a player, implies the creation of "a system in which the success of the 
participant's game depends on his skills and knowledge that can be transferred to the real world."

The use of gamification in education will help solve the following problems:

- update the knowledge gained during the theoretical courses;

- teach the student to act in situations of extracurricular activities;

- teach the student to make decisions, including the situation of lack or inconsistency of information;

- motivate the student to explore a difficult question.

A striking example of the use of gamification in education - launched in 2014 in one of the American schools system of World of Classcraft, similar to the computer game World of Warcraft [7].

Augmented reality (AR) is a modern technology that allows you to connect the real world and the virtual environment, ensuring their synchronous interaction. With the help of AR technology, virtual objects can be integrated into the material world: an augmented reality camera uses AR programs to capture reality and look for predetermined target points in it - markers to which virtual objects are attached. AR technology can combine virtual and tangible objects, ensure their interaction in real time and use three-dimensional objects. AR is becoming an increasingly popular technology that can be used on desktops, laptops, portable devices and smartphones. AR applications work with three-dimensional objects, texts, images, videos and animations, combine them and apply them simultaneously, allowing users to interact freely with events, information and objects. Modern smartphones are increasing the number of users of applications of this type. The lives of many people are literally in the palm of their hand - in their mobile device, and this life can be even more diverse with the help of AR [10].

The potential of AR for education is just beginning to unfold, as the ability to interact with virtual and real objects makes the learning process more exciting, visual and dynamic. In addition, augmented reality technologies integrated into the educational process stimulate students' creative thinking and develop problemsolving skills, as well as provide learning flexibility. Although AR has great potential, there are still many practical problems that need to be addressed before the widespread introduction of this technology in educational practices.

The analysis of publications related to the use of $\mathrm{AR}$ in higher education also notes the high potential of this technology in various areas. For example, the results of using augmented reality tools for teaching Chinese show that AR helps students write their first paragraph much faster and learn Chinese writing. When comparing educational AR-materials and educational videos on YouTube as part of mastering a software development course, AR-content turned out to be more effective, its application helped to increase students' interest and involvement. Many other researchers also confirm the motivation and involvement of students who are encouraged to use augmented reality applications in the learning process.

When comparing AR technology and interactive simulation methods, no significant difference in terms of students' learning ability and involvement was 
observed, but a significant advantage of AR in terms of information perception was noted.

The following appendix shows in augmented reality models of chemical elements, as well as the possibility of connecting these elements. This exciting interactive application will attract students' attention, focus their attention and make the learning process more interesting [6].

In the literature review, the most common research on the use of AR is in postgraduate education. Examples from the field of architectural education speak in favor of AR technologies; the same conclusions are made for the disciplines of science, where dynamic content allows better mastering of the material and contributes to the progress of research projects of graduate students. In exact sciences and engineering AR-technologies promote the best spatial perception, it is confirmed by researches in the field of mathematical education, mechanical engineering. AR systems with Kinect technology are successfully used in physical and mathematical education. In the humanities, the use of AR helps to reduce cognitive load, while increasing the motivation and positive mood of students. There are studies in the field of medical education, when the training of dentists with the use of mobile AR has become a simple effective tool for knowledge transfer. The study of history with the help of augmented reality applications opens up great prospects, both in terms of content creation opportunities and positions of emotionality and involvement in the educational process.

Separately, we can note the appearance of articles with elements of augmented reality in scientific journals. One of the first such publications was the article "The reality of Quantorium: training young people for the digital economy", published in early 2020 in the journal "Innovation".

Trying different advanced and non-standard educational approaches in practice, we give students a course for advanced development that meets the interests of society, the individual and potential employers in the future.

Social networks and blogs, video chat and video conferencing programs, 3D communications systems, cloud services and many other tools that can be used to modernize the full-time learning process, as well as to create a theoretical basis for an online course at a distance training [9].

Let us consider, which components of information culture develop better and worse in terms of distance learning.

Audiovisual aspect of IC is audiovisual culture. The means of active formation of audiovisual culture is audiovisual learning technology, which means a systematic method of development and use of media intended for human perception through two channels simultaneously (auditory and visual) using appropriate technical devices based on patterns, principles and features of presentation and perception of audiovisual information.

Modern technical means of implementing audiovisual technology include mainly electronic - television, video equipment, personal computers. However, passive consumption of audiovisual products, which is included in the system of educational process, does not lead to comprehension and memorization of 
educationally significant information, nor to its transition into personally significant knowledge and experience. The use of audiovisual technologies requires a certain readiness of the subjects of the educational process (both for students and teachers) to work in the new information environment.

Semiotic culture implies a single, consistent and appropriate use of symbolic elements within one system and the establishment of a clear correspondence between these elements and their verbal description, as well as assessing their impact on the relationship between sender and recipient and further development of these relationships and interactions. The defining part of semiotic culture is the conceptualterminological culture, because terminology is a linguistic representation of a system of scientific (and any other) concepts. Conceptual and terminological culture should be inherent in the representation of scientific knowledge and the process of knowledge transfer.

Successful communicative behavior of the teacher largely depends on the ability to think, accurately and dynamically convey these thoughts to learners; the teacher's awareness of the pedagogical task; the ability to take into account the nature of relationships with students; the novelty and expressiveness of language; the authority of the teacher; the ability to understand the mental state of the student by external signs, "read on the face"; the skills of self-presentation of the teacher, his selfanalysis, self-control, self-realization.

Technological culture is the result of a fairly in-depth analysis of the development of social and pedagogical reality in the world. According to Galeta Y.V. “... one of the values of modern culture is denoted by the concept of manufacturability and related reproducibility. Another, no less significant value is the search and related creativity "[3].

Discussion. The technological culture of the education specialist is not yet spoken of directly, but the issues of design, development, use of educational (pedagogical) technologies are very widely discussed in scientific, methodological and educational literature. The problem of pedagogical technologies is multifaceted, it is reflected in the close relationship of psychological and pedagogical, didactic, technical and organizational aspects. It is also relevant for higher pedagogical education because a modern pedagogical university prepares specialists for different types of educational systems and institutions. And such training is provided both through multilevel and variety of specialties, and through mastering by the future expert of various types of educational technologies in the conditions of distance learning.

Conclusions. Distance education is a necessary condition for the formation of information culture of the future teacher. The Internet and digitalization of education provide an opportunity to develop the main components of information culture (audiovisual aspect, semiotic, technological and partly communicative). But on the other hand, the emotional character is lost from live communication and learning, increasing the formalization of the educational process.

Author contributions. The authors contributed equally.

Disclosure statement. The authors do not have any conflict of interest. 


\section{References:}

1. Bykova N. N., Baulin E. A. (2014), Dystantsyonnye tekhnolohyy v obrazovanyy kak faktor razvytyia informatsyonnoi kultury studenta [Distance learning technologies in education as a factor of development student information culture] [in Russian]

2. Galeta Y.V. (2011), Informatsiina kultura v profesiinii pidhotovtsi maibutnoho pedahoha [Information culture in the professional training of future teachers], Ridna Shkola, №11 [in Ukrainian]

3. Galeta Y.V. (2012), Informatsiina kultura v profesiinii pidhotovtsi suchasnoho pedahoha [Information culture in professional training modern teacher], Naukovi Zapysky, №102 [in Ukrainian]

4. Gurevich R.S., Gordiychuk G.B., LL Konoshevsky L.L., (2007), Osvitnie seredovyshche dlia pidhotovky maibutnikh pedahohiv zasobamy ikt [Educational environment for future ICT teachers], $348 \mathrm{~s}$. [in Russian]

5.Isaev, I.F. (2002), Professionaljno-pedagogicheskaya kuljtura prepodavatelya [Professional and pedagogical culture of the teacher] [In Russian]

6. Kiryanov A. E. (2020), Tekhnolohyy dopolnennoi realnosty v sfere obrazovanyia [Augmented reality technologies in education] / Resource access mode: http://kvantorium37.ru/texnologii-dopolnennoj-realnostiv-sfere-obrazovaniya [in Russian]

7. Kolotygina A.O. (2016), Yspolzovanye heimyfykatsyy v obuchenyy studentov vuzov [Use of gamification in teaching university students], International Journal of Humanities and Natural Sciences, vol.1, part 1, 124128 s. [In Russian]

8. Kulish, A., Radul, V., Haleta, Y., Filonenko, O., Karikh, I. The Newest Digital Technologies in Education and The Prospects of Their Implementation in Ukraine. Propósitos y Representaciones, 8 (SPE2), e684. Doi: http://dx.doi.org/10.20511/pyr2020.v8nSPE2.684

9. Lyamin A.V., Khobotova A.R., Chezhin M.S. (2015), Yspolzovanye sotsyalnikh setei v obrazovanyy [Using social networks in education], St. Petersburg: ITMO Unyversytet, 67 s. [In Russian]

10. Redko T. (2020), Dopolnennaia realnost $v$ sfere obuchenyia [Augmented reality in education] / Resource access mode: https://lookinar.com/ru/prymenenye-ar-vr-v-obrazovanyy/ [in Russian]

11. Vokhrihsheva, M.G. (1997), Formirovanie nauki ob informacionnoyj kuljture [Formation of the science of information culture], Problemih informacionnoyj kuljturih [In Russian] 